\title{
Satisfaction with general functionality and safety of travel in relation to residential environment and satisfaction with transport modes
}

\author{
Hanne Tiikkaja*i(B, Heikki Liimatainen and Markus Pöllänen
}

\begin{abstract}
The objective of this paper is to study 1) do people living in certain residential environments express more dissatisfaction with general functionality and safety of travel, 2) is dissatisfaction with general functionality and safety of travel related to dissatisfaction with certain transport modes, 3) is the residential environment related to mode-specific travel satisfaction mediated by satisfaction with general functionality and safety of travel, and 4) is dissatisfaction with general functionality and safety of travel related to use of different transport modes. The analyses are based on a Finnish survey (representative sample of 17,996 people, response rate 29.7\%) on citizen satisfaction with the transport system and travel chains. Three groups, the satisfied, the neither satisfied nor dissatisfied and the dissatisfied, are analysed according to their residential environment, satisfaction with different transport modes and the use of the modes. The results indicate that the residential environment and the satisfaction with general functionality and safety of travel are related. Results suggest that satisfaction with different modes is partly related to lower options offered by the residential environment and higher expectations towards the residential environment. However, satisfaction with general functionality and safety of travel does not relate to higher expectations in a similar way. Findings from this study indicate that satisfaction with daily travel is a phenomenon related to the travel options offered by the residential environment.
\end{abstract}

Keywords: Satisfaction, Dissatisfaction, Travel, Transport mode, Transport mode choice, Residential environment

\section{Introduction}

Different residential environments are divergent in terms of transport mode options, leading to especially notable differences between rural and urban areas. This study takes interest in how different residential areas and the available modes affect satisfaction with general functionality and safety of travel. According to De Vos \& Witlox [7], the term travel satisfaction can be used to refer to either satisfaction with one trip ("trip satisfaction") or satisfaction with travel in general ("satisfaction with daily travel"). Trip satisfaction refers to the experienced emotions during a trip whereas satisfaction with daily travel is

\footnotetext{
* Correspondence: hanne.tiikkaja@tuni.fi

Transport Research Centre Verne, Tampere University, P.O. Box 600, FI-33014 Tampere, Finland
}

\section{Springer Open}

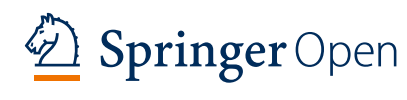

associated with satisfaction with daily travel needs and opportunities [7]. In this study, the terms travel satisfaction and satisfaction with general functionality and safety of travel are used to refer to satisfaction with daily travel.

Building on previous studies, this study uses the framework presented in Fig. 1 to analyse the relationships between the residential environment, satisfaction with general functionality and safety of travel, modespecific travel satisfaction and transport mode choice. This study exploits the results of a survey carried out in Finland with a very large representative sample of 17,996 people and a response rate of $29.7 \%$. The large sample of the survey enables analyses with a detailed classification of the residential environment and on mode-specific travel satisfaction. This study presents a novel approach (c) The Author(s). 2020 Open Access This article is licensed under a Creative Commons Attribution 4.0 International License, which permits use, sharing, adaptation, distribution and reproduction in any medium or format, as long as you give appropriate credit to the original author(s) and the source, provide a link to the Creative Commons licence, and indicate if changes were made. The images or other third party material in this article are included in the article's Creative Commons licence, unless indicated otherwise in a credit line to the material. If material is not included in the article's Creative Commons licence and your intended use is not permitted by statutory regulation or exceeds the permitted use, you will need to obtain permission directly from the copyright holder. To view a copy of this licence, visit http://creativecommons.org/licenses/by/4.0/. 


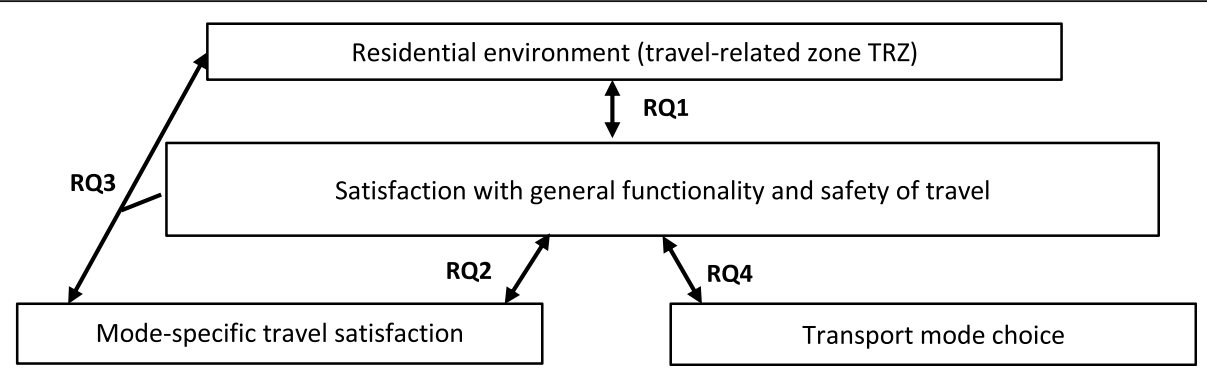

Fig. 1 Analysis framework of this study. RQs refer to the four research questions of this study

in which the survey respondents are divided into three groups according to their satisfaction with general functionality and safety of travel. This enables focusing on the group, which expresses dissatisfaction and therefore should especially be considered in transport system development. This study generates new knowledge about the relation between residential environments and both mode-specific satisfaction and satisfaction with general functionality and safety of travel. Understanding if satisfaction with general functionality and safety of travel and mode satisfaction in Finland are related to more compact or sprawled residential environments can advise policymakers on the needs to create more satisfying travel environments for people. According to Mouratidis et al. [13], such knowledge could offer both important theoretical advancements and empirically-based input for policymakers.

The research questions studied in this paper are 1) do people living in certain residential environments express more dissatisfaction with general functionality and safety of travel, 2) is dissatisfaction with general functionality and safety of travel related to dissatisfaction with certain transport modes, 3) is the residential environment related to mode-specific travel satisfaction mediated by satisfaction with general functionality and safety of travel, and 4) is dissatisfaction with general functionality and safety of travel related to use of different transport modes. Next we present key findings from previous studies related to the four research questions. This is followed by description of methods and data used in our analyses. Thereafter we present the results of our analyses. Finally, we discuss the results and present the conclusions.

\section{Key findings from previous studies}

\subsection{The residential environment and travel satisfaction}

Population density is linked with travel behaviour. Higher population densities are associated with shorter trip distances. However, some studies suggest that the associations between density and travel distance do not reflect a true causality, and instead it is the residential selfselection processes that explain the results [22]. Observed differences in travel behaviour or mode choice in different areas may be due to residential self-selection rather than objective travel choices, and people, who choose a certain type of residential area, tend to travel in certain ways [12]. According to Scheiner [20], residential self-selection in travel behaviour seeks to answer whether geographical differences in travel behaviour are caused by the individual, social or psychological characteristics of people that determine their residential choice and the spatial context they live in rather than the urban form and the opportunities provided by it. Both travel preferences and residential preferences have been found to play a significant role in residential choice [20]. However, a recent study by De Vos and Alemi [5] suggests that young adults might choose to live in urban locations based on other attributes, such as closeness to activities and smaller housing units, rather than the transport options provided by the location, indicating that travel attitudes are not often in line with the chosen residential location and that there could be a limited self-selection effect.

De Vos and Witlox [7] argue that attitudes affect directly the transport mode choice as well as the residential choice, which in turn affects the use of a certain transport mode and trip length. A positive attitude towards travel might influence the choice of neighbourhood making it possible to minimize travel or make trips that are longer in time and distance [7]. Residential relocation enables people to make trips that are more satisfactory and therefore might influence travel satisfaction [6].

\subsection{Mode-specific travel satisfaction, general travel satisfaction and the residential environment}

According to De Vos [4], the results of numerous studies, which have analysed the effect of transport mode choice on travel satisfaction indicate that the users of public transport, bus in particular, are the least satisfied whereas the car users are often found to be the most satisfied. However, Friman et al. [9] have noted that using active transport modes (walking and cycling) has a more positive effect on travel satisfaction than the use of passive transport modes. 
Public transport has been studied widely to identify the key attributes, which affect how public transport is perceived by customers [27]. Customer satisfaction can be measured using subjective traveller perceptions, or objectively with performance measurements [1]. For public transport satisfaction, safety and security issues were recognised as key attributes by e.g. Mouwen [14], Guirao et al. [10] and Redman et al. [18]. Assessing satisfaction with public transport system and building on Maslow's hierarchy of needs, Allen et al. [2] considered that hierarchy of needs for public transport composes of three elements: functional, security and hedonic attributes. Security attributes include both security against traffic accidents and assaults as well as the perception of safety. According to Allen et al. [2], this needs hierarchy in public transport should be used in future customer satisfaction studies. For car satisfaction, costs of buying, owning and driving a car [9] as well as congestion, experienced safety, travel time reliability, parking availability and other road users [7] have been found to play an important role. Some of the land-use trends, such as urban sprawl, also encourage the use of car [18]. Walking and cycling have been found to be affected by attributes such as weather, personal fitness level and the quality of infrastructure [7]. For the use of bicycle, urban form and travel distance, road infrastructure, safety and travel time play an important role [9]. Pedestrian satisfaction is also related to the aesthetics of the surroundings [7].

Residential neighbourhood type dissonance can be defined as an incongruence in land use patterns between the neighbourhood currently resided and the preferred structure of the residential environment [21]. Thus, residential dissonance occurs, when people choose a neighbourhood that does not match their travel and residential preferences, and the residents are forced to use less desired modes [4]. According to De Vos [4], this might result in trips that are perceived negative and to low mode-specific travel satisfaction.

The concept of a value-action gap describes the discrepancy between attitudes and behaviour, such as mode choice and mode preference. This gap may be due to the presence of subjective norms and behavioural control, or the lack of skills and the presence of certain barriers. One of these barriers is the residential environment, which can be seen as an obstacle in choosing a certain transport mode. For example, people living further from key locations might be forced to choose a motorised transport mode despite their preferences [4]. Determinants of travel satisfaction with public transport have also been found to vary according to location, and both the size of urban area and the socio-demographic profile of the area affect the attributes influencing travel satisfaction [1]. Forced car ownership, which was originally associated with rural areas with lack of transport options, has also been associated with people living in more central urban areas with income and accessibility related challenges [3].

\subsection{Travel satisfaction, travel behaviour and transport mode choice}

People evaluate different transport modes according to their needs and values, and experience different levels of satisfaction with modes according to how the mode meets these priorities. However, there are indications that personal values and motivations are more important in mode choice than traditional characteristics of different modes, such as travel time or costs. Therefore, it is important to analyse travel satisfaction and its relation to travel behaviour with both traditional measures, such as service level aspects, as well as more psychological variables [24].

Travel-related attitudes have been found to affect travel behaviour, and transport mode choice in particular. Positive attitude towards a certain transport mode results in a higher probability to use that mode in future. The attitude towards a certain mode is affected both directly and indirectly through the residential choice. People might choose to live in a neighbourhood that enables them to make satisfying trips and use their preferred mode. Positive attitude towards travel might result in choosing a residential location that supports longer daily trips whereas negative attitude could make people choose a residential location that minimizes travel [7]. The dissonance between attitudes and behaviour can result in discomfort or dissatisfaction [4]. However, as De Vos [4] has noted, in some repetitive trips, such as journeys to work, transport mode choice might have become habitual and might be based on past behaviour rather than attitudes towards transport modes.

\section{Methods and data}

Analyses in this paper are based on data collected with the "Survey on citizen satisfaction with the transport system and travel chains 2017" by the Finnish Transport Agency. Similar survey is carried out biannually and the data used for this paper was collected in spring 2017 with a representative sample of 17,996 people, 5350 respondents, and a response rate of $29.7 \%$. The purpose of the survey is to provide information on people's perceptions on the service level of travel, transport chains and the transport system [11]. The data analysis and its connection with the research questions of this study is presented in Fig. 2.

\subsection{Areal classifications and residential environments}

In order to analyse the survey data in this study, two different types of areal classifications are used. The first 


\begin{tabular}{|c|c|c|c|c|}
\hline \multirow[b]{2}{*}{ 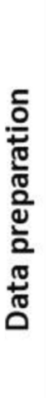 } & Original survey data & \multicolumn{2}{|c|}{ Areal classification: residential environment } & Sufficiency of data \\
\hline & $\begin{array}{l}\text { Data from the } \\
\text { Survey on citizen } \\
\text { satisfaction with } \\
\text { the transport } \\
\text { system and travel } \\
\text { chains } 2017 \\
(n=5,350)\end{array}$ & \multicolumn{2}{|c|}{$\begin{array}{l}\text { Reclassifying travel related zones of the } \\
\text { urban form into residential areas: } \\
\text { 1) Pedestrian-oriented zones }(n=538) \\
\text { 2) Edges of city centre }(n=400) \\
\text { 3) Public transport-oriented zones } \\
\text { ( } n=1,533) \\
\text { 4) Car-oriented zones }(n=1,397) \\
\text { 5) Unclassified }(n=1,482)\end{array}$} & $\begin{array}{l}\text { Excluding cases }(\mathbf{n}=\mathbf{1 , 5 0 8 )} \text { with } \\
\text { insufficient data: } \\
\text { 1) Related to travel related } \\
\text { zones of the urban form: } \\
\text { unclassified excluded } \\
\text { 2) Related to population size: } \\
\text { regions with less than } 20,000 \\
\text { inhabitants excluded }\end{array}$ \\
\hline \multirow[b]{2}{*}{$\frac{\text { an }}{\frac{2}{2}}$} & \\
\hline & \multicolumn{4}{|c|}{$\begin{array}{l}\text { From the data }(n=3,842) \text {, three groups of survey respondents formed based on satisfaction with general } \\
\text { functionality and safety of travel: } \\
\text { 1) The dissatisfied }(n=236 \text {; including very dissatisfied }(n=26) \text { and dissatisfied }(n=210)) \\
\text { 2) The neither satisfied nor dissatisfied }(n=723) \\
\text { 3) The satisfied }(n=2,684 \text {; including very satisfied }(n=232) \text { and satisfied }(n=2,452))\end{array}$} \\
\hline 듬 & \multicolumn{4}{|c|}{$\begin{array}{l}\text { Analysing the connections between satisfaction and the residential area and satisfaction in relation to } \\
\text { different transport modes using cross tabulation and Pearson Chi-Square test }\end{array}$} \\
\hline ֻัญ & \multicolumn{2}{|c|}{$\begin{array}{l}\text { RQ1: Do people living in certain residential environments } \\
\text { express more dissatisfaction with general functionality and } \\
\text { safety of travel? }\end{array}$} & \multicolumn{2}{|c|}{$\begin{array}{l}\text { RQ2: Is dissatisfaction with general functionality and } \\
\text { safety of travel related to dissatisfaction with certain } \\
\text { transport modes? }\end{array}$} \\
\hline$\frac{\widetilde{d}}{\partial}$ & \multicolumn{2}{|c|}{$\begin{array}{l}\text { Cross tabulation: residential environment and satisfaction } \\
\text { with general functionality and safety of travel }\end{array}$} & \multicolumn{2}{|c|}{$\begin{array}{l}\text { Cross tabulation: satisfaction with general functionality } \\
\text { and safety of travel and mode satisfaction }\end{array}$} \\
\hline ֻே & \multicolumn{2}{|c|}{$\begin{array}{l}\text { RQ3: Is the residential environment related to mode- } \\
\text { specific travel satisfaction mediated by satisfaction with } \\
\text { general functionality and safety of travel? }\end{array}$} & \multicolumn{2}{|c|}{$\begin{array}{l}\text { RQ4: Is dissatisfaction with general functionality and } \\
\text { safety of travel related to use of different transport } \\
\text { modes? }\end{array}$} \\
\hline$\frac{\frac{n}{n}}{\frac{n}{\frac{n}{c}}}$ & \multicolumn{2}{|c|}{$\begin{array}{l}\text { Cross tabulation: satisfaction with general functionality and } \\
\text { safety of travel and mode satisfaction in different } \\
\text { residential environments }\end{array}$} & \multicolumn{2}{|c|}{$\begin{array}{l}\text { Cross tabulation: the use of different transport modes and } \\
\text { satisfaction with general functionality and safety of travel }\end{array}$} \\
\hline
\end{tabular}

Fig. 2 Data analysis and its connection with the research questions of the study

areal classification includes travel related zones introduced by Finnish Environment Institute in the monitoring system of spatial structure and urban form. This classification is often used in Finnish urban studies to describe the transport supply and urban form of the location and is closely linked to the model of three urban fabrics, a concept used by Peter Newman and Jeffrey Kenworthy [15, 16] and Newman et al. [17]. Finnish Environment Institute [8] has used $250 \mathrm{~m} \times 250 \mathrm{~m}$ grid cells to classify areas into travel related zones (TRZ) based on area's location in the urban form and their public transport supply. The main categories are pedestrian zones, public transport zones and car zones. In pedestrian zones opportunities for daily travel are diverse and most of the travel is conducted by foot. Edges of city centre are located $1-3 \mathrm{~km}$ from the pedestrian zone and the availability of public transport varies. The pedestrian zones in subcentres are areas of one kilometre in width. Public transport (PT) zones are divided into intensive PT and basic PT with different attributes for PT frequency. In car zones, public transport supply is poor, the use of public transport is rare, and a high share of population owns a car ( [25], p. 19-21). These main categories can be divided into more specific zones according to the attributes of the area.

The survey data included information about the respondent's residential TRZ. In the original survey data, the zones were classified as 1) zones with good preconditions for pedestrian and bicycle traffic of city centre, 2) edges of city centre, 3 ) intensive public transport zones, 
4) basic public transport zones, 5) edges of city centre that are also basic PT zones, 6) edges of city centre that are also intensive PT zones, 7) poor PT zones, 8) caroriented zones, 9) zones in subcentre with good preconditions for pedestrian and bicycle traffic, 10) subcentres that are also PT zones, 11) subcentres that are also intensive PT zones, and 12) unclassified urban areas or outside urban areas. The original TRZ classification was found to be too specific in relation to the available survey data and thus the subzones of the original zone allocation were reclassified into new main zones. The main categories used in this paper are A) zones with good preconditions for pedestrian and bicycle traffic (later referred to as 'pedestrian-oriented zone') that includes original zones 1 and 9, B) 'edges of city centre' that includes original zone 2, C) 'public transport-oriented zones' that includes original zones 3, 4, 5, 6, 10 and 11 and D) 'car-oriented zones', which include original zones 7 and 8. Unclassified urban areas or zones outside urban areas were not included in analyses (Table 1). This classification is used in our analyses and is referred to as 'residential environment'.

The second areal classification to categorise areas in Finland is based the location and population size of the area. Seven (7) distinct geographical areas can be recognised, of which one, the areas with population less than 20,000, was excluded from the analysis. This exclusion was made as after the classification of travel related zones it was found that the areas with population less than 20,000 inhabitants $(n=617)$ were mostly located in unclassified TRZ locations $(n=591)$ and no results could be drawn from the small remaining sample $(n=26)$.

\subsection{Measuring satisfaction and grouping the respondents according to their level of satisfaction}

In previous studies, travel satisfaction has been measured through a single question about experienced travel satisfaction, a question about satisfaction with one trip or satisfaction with different elements of the trip [23]. In this paper, travel satisfaction is analysed using responses to the survey question about satisfaction with general functionality and safety of travel and the questions about overall satisfaction with different modes (see Table 2). Before answering the question on the overall satisfaction towards a specific transport mode, the respondents had considered several elements, which affect the particular mode, e.g. the amount and condition of pedestrian paths related to walking. The different elements that the respondents were asked to assess related to their satisfaction in different transport modes is presented in Additional file 1. In all questions, the satisfaction was asked on a 5-step scale (very dissatisfied, dissatisfied, neither satisfied nor dissatisfied, satisfied, very satisfied) plus the option "I cannot say".

Before the respondents gave an answer on their satisfaction with general functionality and safety of travel in the end of the survey, they had been asked multiple questions considering the satisfaction with different transport modes and their elements in their own residential environment and on long-distance domestic journeys. Thus, the respondents had been thinking about many aspects related to satisfaction before they gave their answer on satisfaction with different modes and the general functionality and safety of travel. The respondents were asked to assess their satisfaction with safety, both traffic safety and other safety aspects, in different transport modes (see Additional file 1). It is worth noting that in this question, the respondents considered the two elements (general functionality and safety of travel) together as one issue, but the respondents can interpret and emphasise either of the two differently when considering their response. Therefore, from the answers to this particular question, it cannot be analysed how the two elements are weighted and assessed. Thus, a

Table 1 Number of survey respondents according to different areal classifications

\begin{tabular}{|c|c|c|c|c|c|c|}
\hline \multirow{2}{*}{$\begin{array}{l}\text { Classification based on population size in } \\
\text { the area }\end{array}$} & \multicolumn{5}{|c|}{ Classification based on travel related zones (TRZ) of the urban form } & \multirow[b]{2}{*}{ Total } \\
\hline & $\begin{array}{l}\text { pedestrian-oriented } \\
\text { zone }\end{array}$ & $\begin{array}{l}\text { edges of city } \\
\text { centre }\end{array}$ & $\begin{array}{l}\text { public transport- } \\
\text { oriented zone }\end{array}$ & $\begin{array}{l}\text { car-oriented } \\
\text { zone }\end{array}$ & $\begin{array}{l}\text { unclassified } \\
\text { (excluded) }\end{array}$ & \\
\hline 1. Capital region & 59 & 2 & 427 & 73 & 2 & 563 \\
\hline $\begin{array}{l}\text { 2. Other parts of Uusimaa and Riihimäki } \\
\text { region }\end{array}$ & 114 & 98 & 207 & 291 & 185 & 895 \\
\hline 3. Tampere and Turku region & 56 & 4 & 296 & 119 & 48 & 523 \\
\hline 4. Jyväskylä, Kuopio, Lahti and Oulu region & 71 & 30 & 208 & 153 & 144 & 606 \\
\hline 5. 40,000-90,000 inhabitants' regions & 137 & 109 & 265 & 412 & 247 & 1170 \\
\hline 6. $20,000-40,000$ inhabitants' regions & 101 & 157 & 126 & 327 & 265 & 976 \\
\hline $\begin{array}{l}\text { 7. Regions with less than } 20,000 \\
\text { inhabitants (excluded) }\end{array}$ & 0 & 0 & 4 & 22 & 591 & 617 \\
\hline Total & 538 & 400 & 1533 & 1397 & 1482 & 5350 \\
\hline
\end{tabular}

Excluded refers to classifications on which data is not analysed 
Table 2 Questions in the survey and grouping of the respondents and responses

\begin{tabular}{|c|c|c|c|c|}
\hline \multirow[t]{3}{*}{ Object of satisfaction } & \multirow[t]{3}{*}{ Question in the survey } & \multicolumn{3}{|c|}{ Answering options (+ I cannot say, excluded from the analyses) } \\
\hline & & $\begin{array}{ll}\text { very } & \text { dissatisfied } \\
\text { dissatisfied } & \end{array}$ & $\begin{array}{l}\text { neither satisfied nor } \\
\text { dissatisfied }\end{array}$ & $\begin{array}{ll}\text { satisfied } & \text { very } \\
& \text { satisfiec }\end{array}$ \\
\hline & & \multicolumn{3}{|c|}{ Grouping of the respondents } \\
\hline $\begin{array}{l}\text { Satisfaction with the } \\
\text { general functionality } \\
\text { and safety of travel }\end{array}$ & $\begin{array}{l}\text { On this form you have assessed transport conditions } \\
\text { from different perspectives. As a conclusion we like to } \\
\text { ask, how satisfied are you with the functionality and } \\
\text { safety of your journeys in general. }\end{array}$ & The dissatisfied & $\begin{array}{l}\text { The neither satisfied } \\
\text { nor dissatisfied }\end{array}$ & The satisfied \\
\hline $\begin{array}{l}\text { Satisfaction with } \\
\text { transport modes }\end{array}$ & $\begin{array}{l}\text { What is your general assessment of 1) walking } \\
\text { conditions, 2) cycling conditions, 3) local public } \\
\text { transport, 4) car traffic in your own residential area? } \\
\text { Additionally, in Greater Helsinki general satisfaction } \\
\text { towards different forms of public transport (commuter } \\
\text { train, tram, metro, bus) was asked separately. }\end{array}$ & $\begin{array}{l}\text { Dissatisfied with } \\
\text { transport mode }\end{array}$ & $\begin{array}{l}\text { Neither satisfied nor } \\
\text { dissatisfied with } \\
\text { transport mode }\end{array}$ & $\begin{array}{l}\text { Satisfied with } \\
\text { transport mode }\end{array}$ \\
\hline
\end{tabular}

respondent expressing satisfaction or dissatisfaction towards the general functionality and safety of travel, may be satisfied or dissatisfied with either or both of them.

In the analysis, the respondents were divided into three groups based on their answer concerning satisfaction with the general functionality and safety of travel. Total of 3643 respondents were included in analyses, $6.5 \%$ in the group dissatisfied (n (very dissatisfied) $=26$, $\mathrm{n}($ dissatisfied $)=210), 19.8 \%$ in the group neither satisfied nor dissatisfied $(n=723)$ and $73.7 \%$ in the group satisfied $(\mathrm{n}($ satisfied $)=2452, \mathrm{n}($ very satisfied $)=232)$. The respondents who had answered "I cannot say" $(n=65)$ were excluded. Similar grouping was made with the responses related to the satisfaction with different modes in respondent's own residential environment (see Table 2). Satisfaction with public transport is analysed in both Greater Helsinki area (15 cities and municipalities in the capital region and other parts of Uusimaa and Riihimäki region) and other parts of Finland. Satisfaction with different PT modes (commuter train, tram, metro and bus) was asked only in Greater Helsinki area, but the residential environment is not used in these analyses because there are not enough responses for statistically relevant analysis. The uneven sample sizes between the groups should be noticed when interpreting the results, since it is possible that some deviant respondents might have affected the results in the dissatisfied group more due to small sample size compared to other groups.

\section{Results}

This section is divided according to the four research questions. In the analyses, the results are presented as shares of respondents in the three groups, the satisfied, the neither satisfied nor dissatisfied and the dissatisfied. These groups are uneven in size, but all groups include enough cases for statistical analysis. Analyses (cross tabulation, Pearson Chi-Square test) were conducted using statistics software. As the variables in analyses are categorical, Pearson Chi-Square was used to determine the statistical difference between groups of interest. Statistically significant difference occurs, when sig. $<0.05$ and statistically highly significant difference, if sig. $<$ 0.001 .

\subsection{Results on RQ1: the residential environment and} satisfaction with general functionality and safety of travel When analysing satisfaction with general functionality and safety of travel in relation to the residential environment, the dissatisfied were found to live more often in car-oriented zones compared to the neither satisfied nor dissatisfied or the satisfied. By contrast, the satisfied lived in public transport-oriented and pedestrianoriented zones more often than the dissatisfied or the neither satisfied nor dissatisfied (see Table 3). The results were statistically highly significant (Pearson ChiSquare Value $=32.392, \mathrm{df}=6$, sig. $<0.001$ ).

When looking at the same data from the residential environment's point of view (Table 4), we found that the share of dissatisfied respondents was the highest (9\%) in car-oriented zones. The lowest share of dissatisfied respondents was found in pedestrian-oriented zones (4\%). The results were statistically highly significant (Pearson Chi-Square Value $=32.392, \mathrm{df}=6$, sig. $<0.001$ )

4.2 Results on RQ2: satisfaction with general functionality and safety of travel and mode-specific travel satisfaction and RQ3: the residential environment and mode-specific travel satisfaction

Next, satisfaction with walking, cycling and car use is analysed, after which satisfaction with public transport is analysed in Greater Helsinki and in other parts of Finland. In Figs. 3, 4 and 5, satisfaction with walking, cycling and car use is presented in all residential environments to answer RQ2 and separately in different residential environments to answer RQ3. 
Table 3 Satisfaction with general functionality and safety of travel by group in different residential environments

\begin{tabular}{|c|c|c|c|c|c|}
\hline \multirow[b]{2}{*}{ The groups } & \multirow[b]{2}{*}{ Pedestrian-oriented zone } & \multicolumn{4}{|c|}{ The residential environment } \\
\hline & & Edges of city centre & Public transport-oriented zone & Car-oriented zone & $\overline{\text { Total }}$ \\
\hline The dissatisfied $(n=236)$ & $7.6 \%$ & $11.4 \%$ & $33.9 \%$ & $47.0 \%$ & $100 \%$ \\
\hline $\begin{array}{l}\text { The neither satisfied nor dissatisfied } \\
(\mathrm{n}=723)\end{array}$ & $13.4 \%$ & $12.0 \%$ & $35.7 \%$ & $38.9 \%$ & $100 \%$ \\
\hline The satisfied $(n=2684)$ & $14.6 \%$ & $9.6 \%$ & $42.0 \%$ & $33.8 \%$ & $100 \%$ \\
\hline
\end{tabular}

Figure 3 presents satisfaction with walking among the groups and in different residential environments. Surprisingly, the difference in satisfaction with walking between the satisfied and the dissatisfied was the greatest in pedestrian-oriented zones, where $35 \%$ of the dissatisfied expressed dissatisfaction towards walking and only $2 \%$ of the satisfied had responded being dissatisfied with walking. The results were statistically highly significant, but in pedestrian-oriented zones there were too few cases to draw valid statistical conclusions (33.3\% of cells have expected count less than 5). The statistical results (Pearson Chi-Square Value; df; sig.) were: for all areas $(563.302 ; 4 ;<0.001)$, for pedestrian-oriented zones $(80.365 ; 4 ;<0.001)$, for edges of city centre $(259.605 ; 4$; $<0.001$ ), for public-transport oriented zones (563.302; 4; $<0.001)$, and for car-oriented zones $(180.789 ; 4 ;<0.001)$.

When analysing satisfaction with cycling among the groups in different residential environments, the respondents were found to be more dissatisfied with cycling than with walking (Fig. 4). The results were statistically highly significant. The statistical results (Pearson ChiSquare Value; df; sig.) were: for all environments $(409.899 ; 4 ;<0.001)$, for pedestrian-oriented zones (46.137; $4 ;<0.001)$, for edges of city centre $(51.495 ; 4 ;<$ $0.001)$, for public-transport oriented zones (161.255; 4; $<0.001)$, and for car-oriented zones (157.244; $4 ;<0.001)$.

Satisfaction with car use was analysed similarly in different residential environments and in general (Fig. 5). The share of dissatisfied with car use was large among the dissatisfied in all residential environments. The results were statistically highly significant. The statistical results (Pearson Chi-Square Value; df; sig.) were: for all environments $(752.934 ; 4 ;<0.001)$, for pedestrianoriented zones $(124.095 ; 4 ;<0.001)$, for edges of city centre $(71.848 ; 4 ;<0.001)$, for public-transport oriented zones $(322.236 ; 4 ;<0.001)$, and for car-oriented zones (271.034; 4 ; < 0.001).

Satisfaction with public transport was analysed in two different areas, in Greater Helsinki and other parts of Finland. In other parts of Finland, when analysing the general functionality and safety of travel, $7 \%$ belonged to the group dissatisfied, $20 \%$ to the neither satisfied nor dissatisfied, and $73 \%$ to the satisfied (Fig. 6). The corresponding shares in Greater Helsinki were $7 \%, 18 \%$ and $75 \%$ (Fig. 7). In other parts of Finland, the difference in satisfaction with public transport between the dissatisfied and other groups was clear, and there was only little difference between different residential areas. The results were statistically highly significant, but in pedestrian-oriented zones there were too few cases to draw valid statistical conclusions $(22.2 \%$ of cells have expected count less than 5). The statistical results (Pearson ChiSquare Value; df; sig.) were: for all environments $(453.011 ; 4 ;<0.001)$, for pedestrian-oriented zones $(61.807 ; 4 ;<0.001)$, for edges of city centre (58.233; 4 ; <0.001), for public-transport oriented zones $(179.375 ; 4 ;<0.001)$, and for car-oriented zones (164.976; 4 ; < 0.001).

In Greater Helsinki, the difference in satisfaction with public transport between the dissatisfied and other groups was also clear, but differences between different residential areas could also be found. In the edges of city centre, $88 \%$ of the dissatisfied were dissatisfied with public transport, and even $21 \%$ of the satisfied expressed dissatisfaction with public transport. The results were statistically significant, but in pedestrian-oriented zones and in edges of city centre there were too few cases to

Table 4 Satisfaction with general functionality and safety of travel by the residential environment in different groups

\begin{tabular}{|c|c|c|c|c|}
\hline \multirow[b]{2}{*}{ The residential areas } & \multicolumn{4}{|l|}{ The groups } \\
\hline & The dissatisfied & The neither satisfied nor dissatisfied & The satisfied & Total \\
\hline Pedestrian-oriented zone $(n=506)$ & $3.6 \%$ & $19.2 \%$ & $77.3 \%$ & $100 \%$ \\
\hline Edges of city centre $(n=373)$ & $7.2 \%$ & $23.3 \%$ & $69.4 \%$ & $100 \%$ \\
\hline Public transport-oriented zone $(n=1464)$ & $5.5 \%$ & $17.6 \%$ & $76.9 \%$ & $100 \%$ \\
\hline Car-oriented zone ( $n=3643)$ & $8.5 \%$ & $21.6 \%$ & $69.8 \%$ & $100 \%$ \\
\hline
\end{tabular}



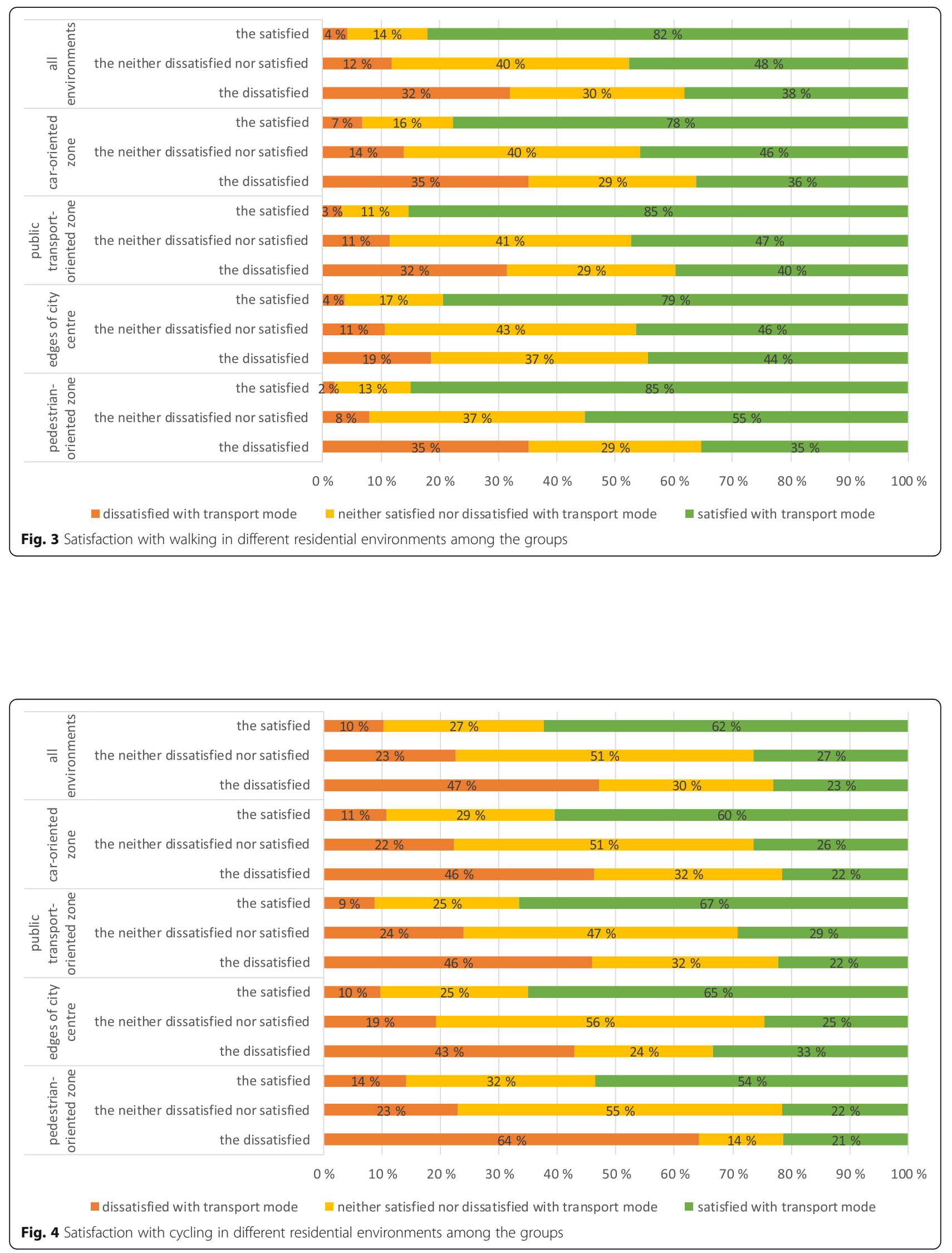

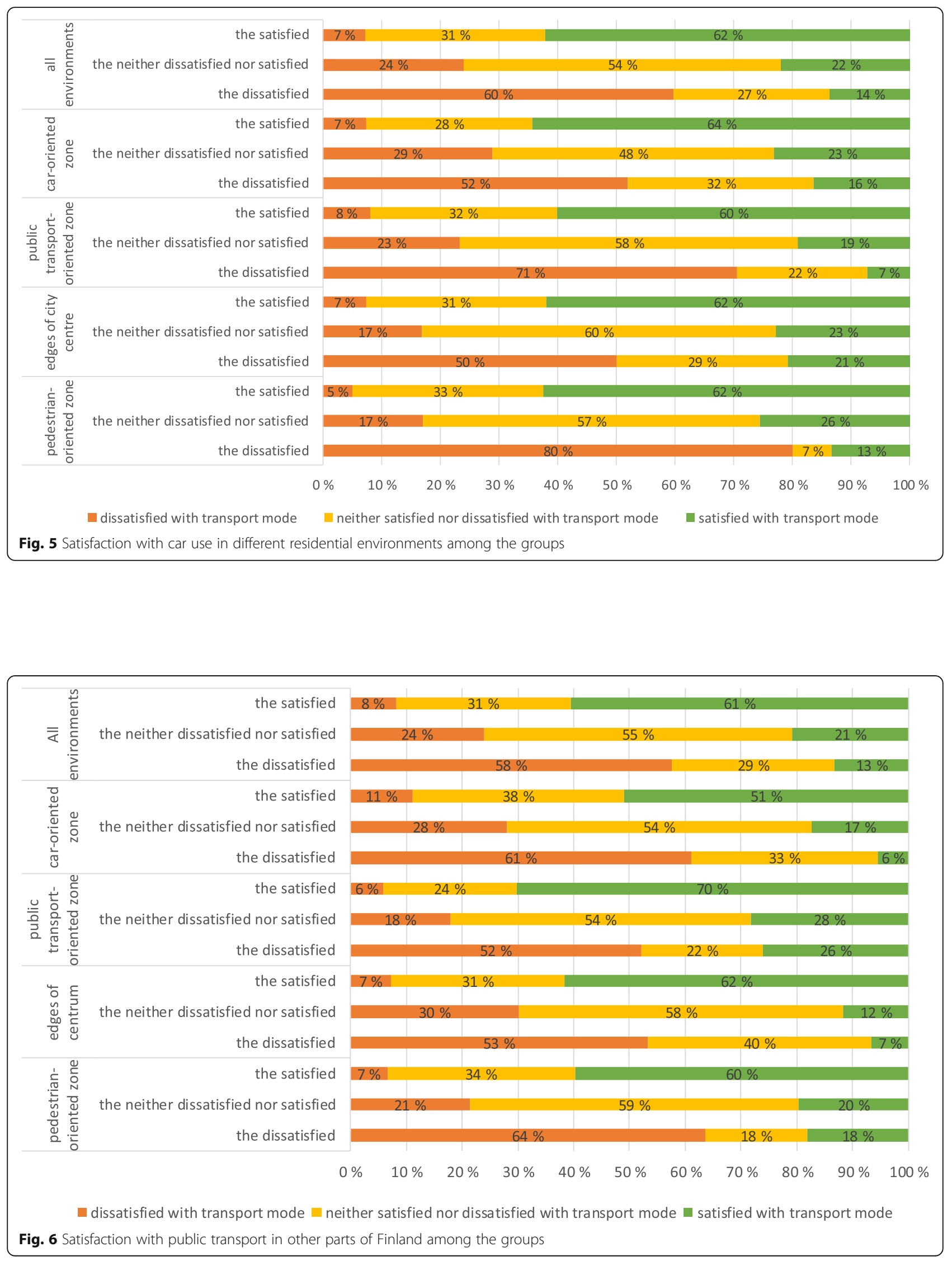


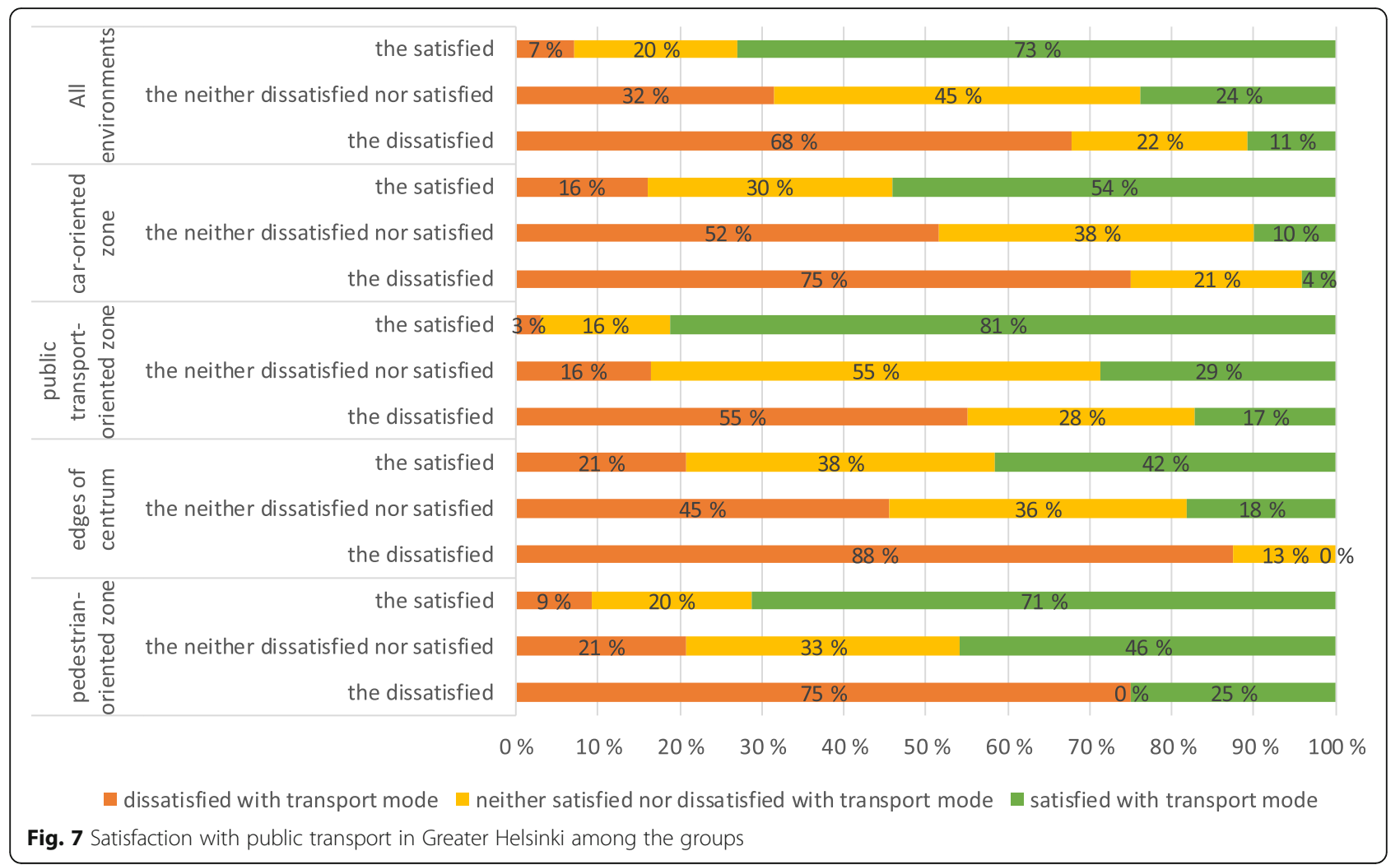

draw valid statistical conclusions $(44.4 \%$ and $66.7 \%$ of cells have expected count less than 5). The statistical results (Pearson Chi-Square Value; df; sig.) were: for all environments $(285.485 ; 4 ;<0.001)$, for pedestrianoriented zones $(18.381 ; 4 ; 0.001)$, for edges of city centre
(12.327; 4; 0.015), for public-transport oriented (185.822; $4 ;<0.001)$, and for car-oriented zones $(65.044 ; 4$; $<0.001)$.

In Greater Helsinki, different public transport modes (commuter train, tram, metro, bus) were analysed

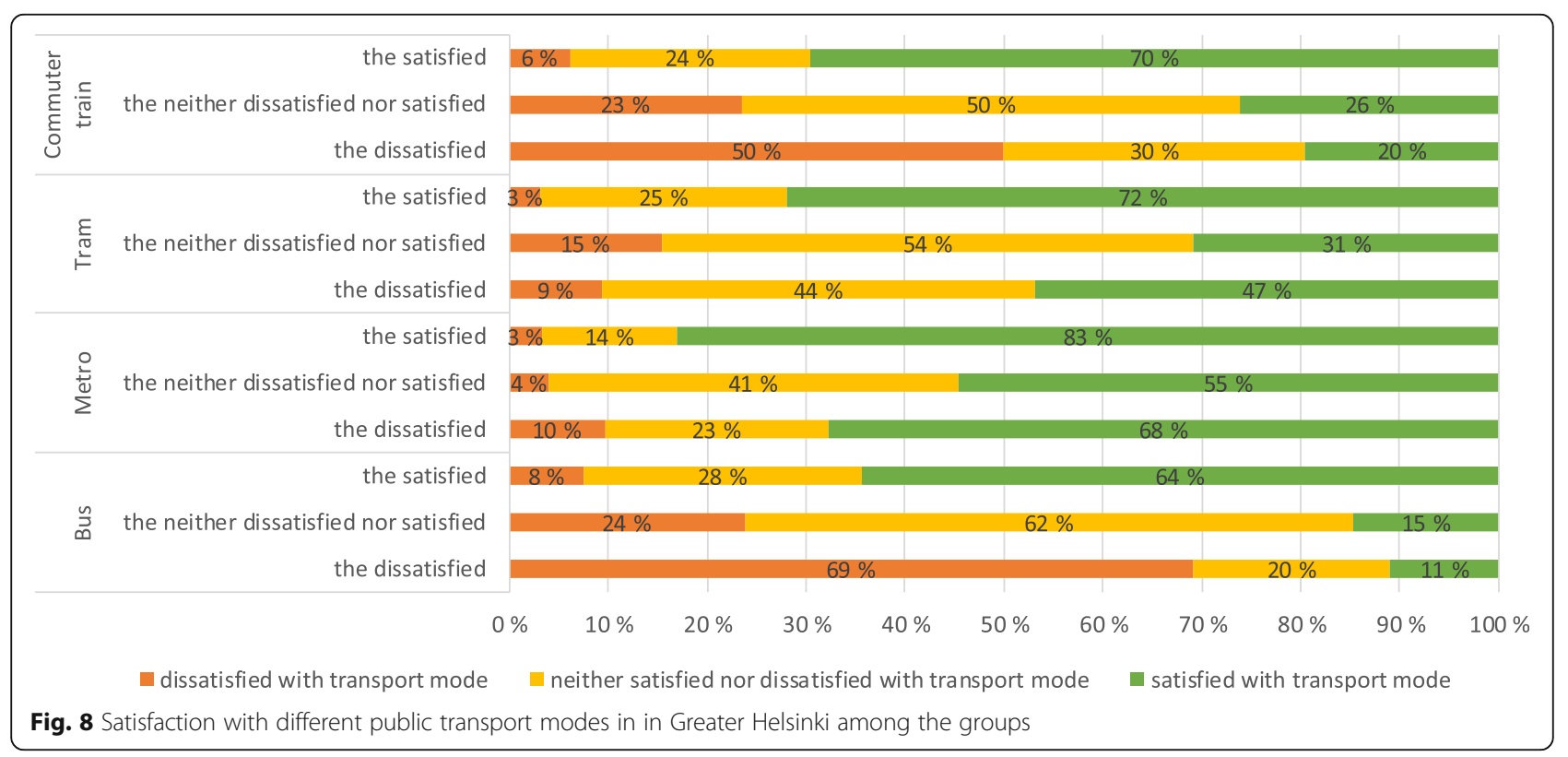




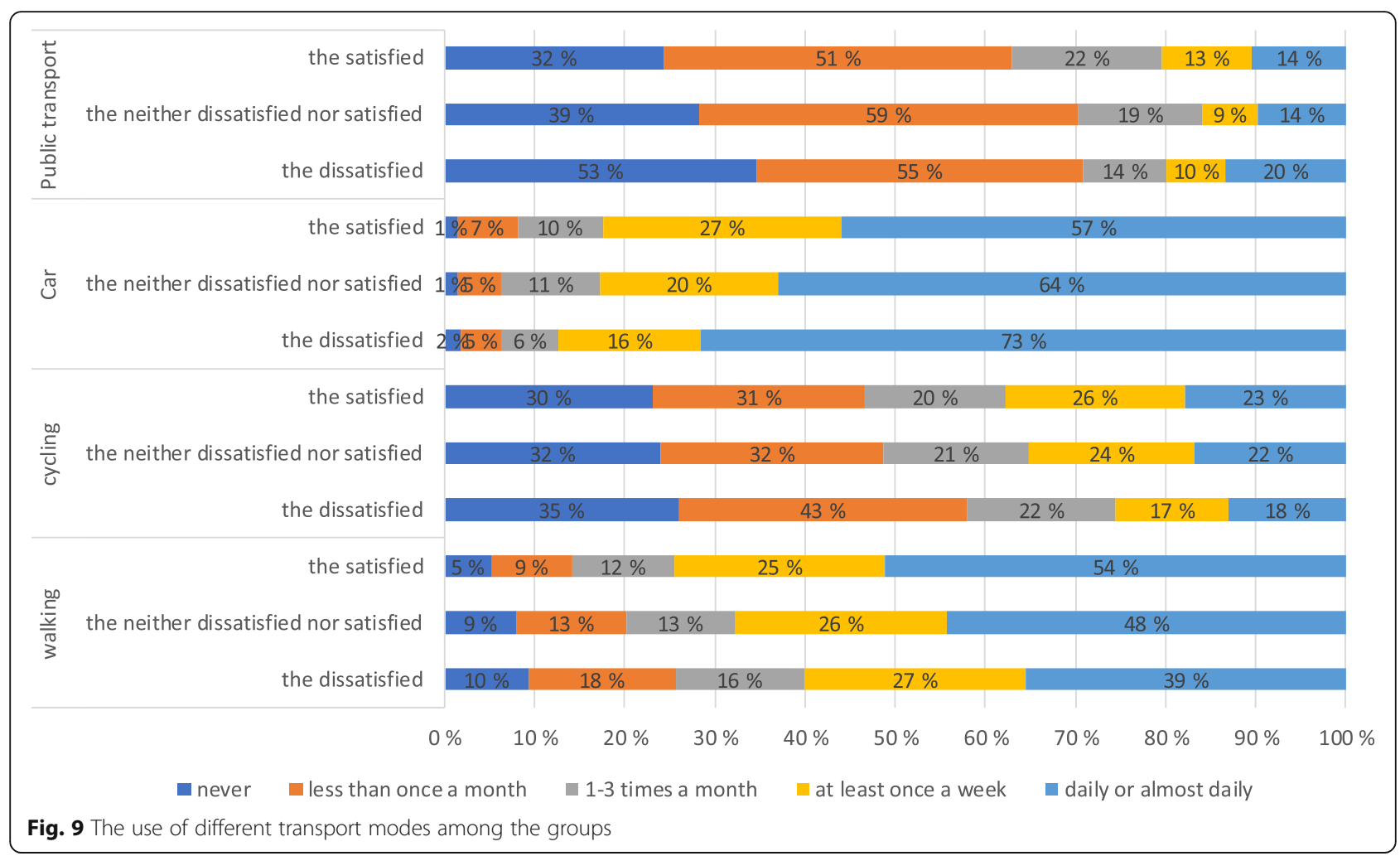

separately (Fig. 8). The results on satisfaction with bus and commuter train showed large differences between the satisfied and the dissatisfied groups, but satisfaction with tram and metro did not. However, in case of tram and metro, the results were not statistically reliable due to the small number of cases in each group (22.2\% of cells have expected count less than 5). The statistical results (Pearson Chi-Square Value; df; sig.) were: for train (148.583; 4; $<0.001)$, for tram $(56.763 ; 4 ; 0.001)$, for metro $(35.619 ; 4$; $0.015)$, and for bus $(257.272 ; 4 ;<0.001)$.

\subsection{Results on RQ4: satisfaction with general functionality and safety of travel and transport mode choice}

The use of different modes and satisfaction with general functionality and safety of travel are presented in Fig. 9. Compared to the satisfied, the dissatisfied responded more often that they never use public transport. $73 \%$ of the dissatisfied used car daily or almost daily, whereas the corresponding share among the satisfied was $57 \%$. The satisfied cycled and walked more often than the dissatisfied. The results were statistically highly significant in walking, car use and public transport, but in cycling the results were not statistically significant. The statistical results (Pearson Chi-Square Value; df; sig.) were: for walking $(38.500 ; 8 ;<0.001)$, for cycling $(14.614 ; 8$; $0.067)$, for car use $(37.448 ; 8 ; 0.001)$, and for public transport $(30.749 ; 8 ;<0.001)$.

\section{Discussion}

Related to the first research question, do people living in certain residential environments express more dissatisfaction with general functionality and safety of travel, the results indicate that the residential environment has linkages with travel satisfaction. The share of dissatisfied respondents was the highest in car-oriented zones, where public transport services are poorer. In the edges of city centre the share of dissatisfied was the second highest. This is somewhat surprising, but it could be due to higher expectations for the functionality of the transport system and the residential environment that, despite relatively central location, fails to meet respondent's expectations related to the transport system and the service it offers. It could be that the edges of city centre are "in between" zones, with public transport services that do not meet the needs and expectations of the residents, and simultaneously with relatively long distances. Two aspects regarding residential location and travel satisfaction are to be considered when analysing travel satisfaction in different residential environments. First, are people forced to travel with less desired transport modes resulting in dissatisfaction, and secondly, have the residents chosen a neighbourhood that supports their preferred mode choice? De Vos [4] found that the travellers using their preferred mode were more satisfied with the chosen transport mode than the travellers using an undesirable mode were. Our results suggest that residential 
neighbourhood type dissonance could be found especially in car-oriented zones where the share of dissatisfied respondents is the largest. In car-oriented zones, some of the dissatisfaction found in this study could be explained through forced car ownership. People with limited alternatives for travel could be forced into car ownership to meet their mobility needs [3]. This could explain why people living further from city centre might experience lower travel satisfaction.

Related to the second research question, the respondents who were dissatisfied with the general functionality and safety of travel were found to be more often dissatisfied with all the transport modes compared to the satisfied or the neither satisfied nor dissatisfied. The difference in mode satisfaction between the satisfied and the dissatisfied groups was the largest in public transport and car use and the smallest in walking. This could be a clue that in areas where public transport is expected to offer good service level, dissatisfaction with public transport relates to dissatisfaction with travel in general.

Related to the third research question, the difference between the groups in satisfaction with walking was found in all residential environments, but perhaps surprisingly, among the dissatisfied the share of dissatisfied with walking was the greatest in pedestrian-oriented zones and in car-oriented zones. This might be similar to public transport, where higher expectations about the residential environment lead to dissatisfaction to some extent. Similar results were found when analysing cycling. Furthermore, satisfaction with car use gave interesting results. In pedestrian-oriented zones, $80 \%$ of the dissatisfied were dissatisfied with car use. Of the satisfied respondents living in pedestrian-oriented zones, only $5 \%$ expressed dissatisfaction with car use. In pedestrianoriented zones with good transport options, dissatisfaction with different transport modes could be explained through residential self-selection. Residential selfselection assumes that people choose their residential location so that it supports the use of their preferred transport mode [21]. When people have chosen a central residential location, they have high expectations considering their residential environment and the available transport options. If these options fail to meet the expectations, dissatisfaction could occur. However, De Vos and Alemi [5] suggest that travel attitudes are not often in line with chosen residential location and that there could be limited self-selection effect among young urban residents. This could also be the case in our results, which show low mode satisfaction in pedestrianoriented zones among the dissatisfied.

Related to the fourth research question, the use of different transport modes was analysed and compared between the satisfied, the neither satisfied nor dissatisfied and the dissatisfied groups. The satisfied walked more often than the dissatisfied, who in turn were more active car-users than the satisfied. This is in line with literature, which indicates that the use of active transport modes has a positive effect on travel satisfaction [9]. These findings also support the result that the dissatisfied live more often in car-oriented zones. Past literature identifies that the users of public transport are the least satisfied. According to De Vos [4], this could be because of the large share of public transport users who are not traveling with their preferred mode. In our analyses the share of people who never use public transport or use it less than once a month is larger among the dissatisfied than among the satisfied. Thus, it can be speculated whether the low use of public transport leads to dissatisfaction or is dissatisfaction the reason public transport is used less.

Our results indicate that people living in residential areas with limited transport options are more dissatisfied with the transport system. People living in residential environments with high expectations are the most satisfied with the functionality and safety of travel in general, but dissatisfied with different transport modes. The results highlight the importance of the residential environment as well as the importance of satisfaction with both car use and public transport that were both found to have the largest differences in mode-specific satisfaction between the satisfied and the dissatisfied groups. Yet, it is worth noticing that in the survey analysed in this study, general satisfaction was measured with a question including both functionality and safety of travel. Therefore, the responses can include satisfaction or dissatisfaction towards either or both of these elements according to each respondent's interpretation.

The study was based on a survey with a very large sample, which enabled detailed analyses. However, even with such a large sample, there were too few cases to draw statistical conclusions in some analyses. The small number of dissatisfied respondents could also have affected the results, since few deviant answers have a larger impact on results compared to large samples, such as the satisfied respondents. Even though the sample sizes are large enough for statistical analysis in all groups, the uneven group sizes should be noticed when considering the results.

\section{Conclusions}

The research questions in this paper were 1) do people living in certain residential environments express more dissatisfaction with general functionality and safety of travel, 2) is dissatisfaction with general functionality and safety of travel related to dissatisfaction with certain transport modes, 3) is the residential environment related to mode-specific travel satisfaction mediated by satisfaction with general functionality and safety of travel, and 4) is dissatisfaction with general functionality and safety of travel related to use of different transport modes. 
Generally, the results imply that Finns have a high travel satisfaction. People living in car-oriented zones expressed dissatisfaction with the general functionality and safety of the travel more often than people living in other residential areas, whereas the share of satisfied was the highest among people living in pedestrian-oriented zones. The ones expressing dissatisfaction with the general functionality and safety of the travel were dissatisfied with all transport modes in every residential environment. The dissatisfied were found to use car more than the satisfied, whereas the satisfied were found to walk more often than the dissatisfied.

The results give additional justification for developing residential environment and transport system towards more pedestrian and public transport-oriented direction. Furthermore, transport system planners can see the results of this study as a reminder to focus more on the level and development of mode-specific satisfaction. The results also give a signal to develop transport system in the edges of city, which is perhaps overlooked in planning.

Further studies could look more into the background variables of the respondents. A survey focusing on residential location choice and satisfaction with travel should be conducted in order to learn more about the occurrence of residential neighbourhood type dissonance and residential self-selection. Future surveys should be conducted in a way, which ensures that enough cases are drawn in every residential environment. In Finland, similar survey as analysed in this paper, is carried out biannually, which enables further studies based on longitudinal approach. Longitudinal analyses could be used to analyse the effects of major changes in transport system, such as opening the new metro line and reorganising the bus routes in Greater Helsinki in the end of 2017. Some studies related to Greater Helsinki public transport system have already been published e.g. by Weckström et al. [26] and Salonen and Toivonen [19].

\section{Supplementary information}

Supplementary information accompanies this paper at https://doi.org/10. 1186/s12544-020-00423-9.

Additional file 1.

\section{Acknowledgements}

The authors would like to thank the former Finnish Transport Agency for permitting the use of the survey data and the anonymous reviewers for their comments and suggestions for improving this paper.

\section{Authors' contributions}

HT and HL designed and conceptualized the study. MP and HT generated the research questions. HT collected findings from previous studies, analysed the data and interpreted results. MP and $\mathrm{HL}$ substantively revised the paper. All authors read and approved the final manuscript. In the revision process, the reviewer comments were considered by all authors and responses were discussed and revisions were conducted together by HT, MP and HL.
Funding

This research is funded by Kone Foundation (grant number b4b919).

\section{Availability of data and materials}

The data analysed in this study is available with permission from the Finnish Transport and Communications Agency Traficom (former Finnish Transport Agency). Restrictions apply to the availability of the data, which was used under license for the current study. Data is not publicly available. However, the data is available from the authors upon reasonable request and with a permission from Traficom.

\section{Competing interests}

The authors declare that they have no competing interests.

Received: 3 July 2019 Accepted: 29 April 2020

Published online: 13 May 2020

\section{References}

1. Abenoza, R. F., Cats, O., \& Susilo, Y. O. (2017). Travel satisfaction with public transport: Determinants, user classes, regional disparities and their evolution Transportation Research Part A, 95, 64-84.

2. Allen, J., Muñozb, J. C., \& de Dios Ortúzar, J. (2019). Understanding public transport satisfaction: Using Maslow's hierarchy of (transit) needs. Transport Policy, 81, 75-94.

3. Curl, A., Clark, J., \& Kearns, A. (2018). Household car adoption and financial distress in deprived urban communities: A case of forced car ownership? Transport Policy, 65, 61-71

4. De Vos, J. (2018). Do people travel with their preferred transport mode? Analysing the extent of transport mode dissonance and its effect on travel satisfaction. Transportation Research Part A, 117, 261-274.

5. De Vos, J., \& Alemi, F. (2020). Are young adults car-loving urbanites? Comparing young and older adults' residential location choice, travel behavior and attitudes. Transportation Research Part A, 132, 986-998.

6. De Vos, J., \& Ettema, D. (2020). Travel and residential change: An introduction. Travel Behaviour and Society, 19, 33-35.

7. De Vos, J., \& Witlox, F. (2017). Travel satisfaction revisited. On the pivotal role of travel satisfaction in conceptualizing a travel behaviour process. Transportation Research Part A, 106, 364-373

8. Finnish Environment Institute 2018. Travel-related Urban Zones as a Planning Tool (Urban Zone 2). http://www.syke.fi/projects/urbanzone2. Accessed 13 July 2018.

9. Friman, M., Gärling, T., Ettema, D., \& Olsson, L. E. (2017). How does travel affect emotional well-being and life satisfaction? Transportation Research Part A, 106, 170-180.

10. Guirao, B., García-Pastor, A., \& López-Lambas, M. E. (2016). The importance of service quality attributes in public transportation: Narrowing the gap between scientific research and practitioners' needs. Transport Policy, 49, 68-77.

11. Kiiskilä, K. \& Tuominen, J. Survey on citizen satisfaction with the transport system and travel chains 2017. Helsinki 2017. Finnish Transport Agency, Planning Department. Research reports of the Finnish Transport Agency 45/ 2017. 81 p+ appendices.

12. Mokhtarian, P. L., \& Cao, X. (2008). Examining the impacts of self-selection on travel behavior: A focus on methodologies. Transportation Research Part B, 42, 204-228.

13. Mouratidis, K., Ettema, D., \& Næss, P. (2019). Urban form, travel behavior, and travel satisfaction. Transportation Research Part A, 129(2019), 306-320.

14. Mouwen, A. (2015). Drivers of customer satisfaction with public transport services. Transportation Research Part A: Policy and Practice, 78, 1-20.

15. Newman, P., \& Kenworthy, J. (1996). The land use - Transport connection. Land Use Policy, 13(1), 1-22.

16. Newman, P., \& Kenworthy, J. (1999). Sustainability and cities: Overcoming automobile dependence (p. 442). Washington D.C: Island Press.

17. Newman, P., Kosonen, L., \& Kenworthy, J. (2016). Theory of urban fabrics: Planning the walking, transit/public transport and automobile/motor car cities for reduced car dependency. The Town Planning Review, 87(4), 429-458.

18. Redman, L., Friman, M., Gärling, T., \& Hartig, T. (2013). Quality attributes of public transport that attract car users: A research review. Transport Policy, 25, 119-127.

19. Salonen, M., \& Toivonen, T. (2013). Modelling travel time in urban networks: Comparable measures for private car and public transport. Journal of Transport Geography, 31, 143-153. 
20. Scheiner, J. (2018). Transport costs seen through the lens of residential selfselection and mobility biographies. Transport Policy, 65, 126-136.

21. Schwanen, T., \& Mokhtarian, P. L. (2005). What affects commute mode choice: Neighborhood physical structure or preferences toward neighborhoods? Journal of Transport Geography, 13, 83-99.

22. Schwanen, T., \& Mokhtarian, P. L. (2005b). What if you live in the wrong neighborhood? The impact of residential neighborhood type dissonance on distance traveled. Transportation Research Part D, 10, 127-151.

23. Singleton, P. A. (2019). Validating the satisfaction with travel scale as a measure of hedonic subjective well-being for commuting in a U.S. city. Transportation Research Part F, 60, 399-414.

24. Susilo, Y. O., \& Cats, O. (2014). Exploring key determinants of trave satisfaction for multi-modal trips by different traveler groups. Transportation Research Part A, 67, 366-380.

25. Söderström, P. Schulman, H. \& Ristimäki, M. 2015. Urban form in the Helsinki and Stockholm City regions. Development of pedestrian, public transport and Car zones. Reports of the Finnish environment institute 16/ 2015. Finnish environment institute. $68 \mathrm{p}$.

26. Weckström, C., Kujala, R., Mladenović, M. N., \& Saramäki, J. (2019). Assessment of large-scale transitions in public transport networks using open timetable data: Case of Helsinki metro extension. Journal of Transport Geography, 79, 102470.

27. Wong, R. C. P., Szeto, W. Y., Yang, L., \& Wong, S. C. (2017). Elderly users' level of satisfaction with public transport services in a high-density and transitoriented city. Journal of Transport and Health, 7, 209-217.

\section{Publisher's Note}

Springer Nature remains neutral with regard to jurisdictional claims in published maps and institutional affiliations.

\section{Submit your manuscript to a SpringerOpen ${ }^{\circ}$ journal and benefit from:}

- Convenient online submission

- Rigorous peer review

- Open access: articles freely available online

- High visibility within the field

- Retaining the copyright to your article

Submit your next manuscript at $\boldsymbol{\nabla}$ springeropen.com 